\title{
Granice dozwolonej prowokacji w świetle art. 24 k.k.
}

\begin{abstract}
The institution of provocation in criminal law is an extremely interesting phenomenon, for it may refer both to people who do not perform any public functions as well as to people who hold such a position. In this perspective, it was necessary to indicate in the article the origin of the word provocation and its etymology. Therefore, one conducted an analysis of various definitions and their components. One also indicated the origin of the eponymous institution and the examples manifested in international body of rulings. In a description of such phenomena as provocation, it is necessary to indicate the responsibility of the person who commits the offence(s) mentioned in Art. 24 of the Penal Code. An interesting element has to do with the indication - in one of the subchapters - of the utilisation of provocation in operation- and situation assessment-related activities, which are a result of the act of law about the Police and about other services.

Finally, one should ask oneself the question about the extent to which one may shift the application of regulations about responsibility, considering the catalogue of institutions which may employ such technique(s)? Therefore, should not one delimit the scope of the competence of organs such as the Public Prosecutor General/Minister of Justice, in order to enhance the efficiency of the system which was mentioned above? The conclusion of the article constitutes an attempt at answering the question about the aforementioned questions and to consider the plausibility of the combining these positions in the context of the subject which is discussed.
\end{abstract}

Key words: provocation, the one who engages in provocation, police, minister of justice, public prosecution service, public prosecutor general, operation- and situation assessmentrelated activities, proceeding

\section{Pochodzenie i znaczenie słowa „prowokacja”}

Analizując aspekt prowokacji na poziomie granic prawnych oraz granic moralnych, należy zastanowić się najpierw nad znaczeniem i poję- 
ciem takiego zachowania. Ogólnie rzecz ujmując, jest to zachowanie mające na celu uzyskanie informacji bądź wymuszenie jakiegoś zachowania u potencjalnego obiektu/ofiary w sposób podstępny i celowy.

Analizując etymologię zjawiska prowokacji, zauważyć można, iż provocator (łac.) wskazuje na osobę wywołującą coś (w dosłownym znaczeniu oznacza „wywołujaccy do walki”), natomiast provocatio - „wywołanie” wyrazy te pochodzą od łacińskiego słowa provocare, czyli wywoływać,

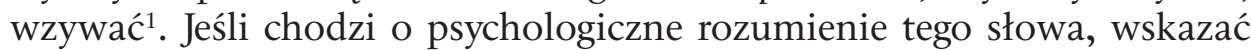
należy, iż jest to świadome wymuszenie określonych przez prowokatora zachowań, działań czy też reakcji u osoby trzeciej, która jest jednocześnie ofiarą. Metody takiego oddziaływania skupiają się na reakcjach nagłych i częstokroć agresywnych. Wymuszane podstępem zachowanie ma na celu wywołanie skutków zwykle szkodliwych dla ofiary i osób powiązanych z nią ${ }^{2}$. Wreszcie, jeśli mowa o znaczeniu pojęcia wykorzystywanego w prawie karnym, prowokacja polega na nakłanianiu osoby do popełnienia przestępstwa, mającego na celu doprowadzenie do wszczęcia postępowania karnego przeciwko tej osobie ${ }^{3}$.

Zdefiniowania tego zjawiska podjął się także A. Taracha, za którym stwierdzić należy, iż są to czynności podejmowane przez państwowe organy, których umocowanie wynika z ustawodawstwa i obejmuje działania tajne lub poufne i które to spełniają funkcje informacyjną, dowodową, wykrywczą, a także profilaktyczną ${ }^{4}$.

Nauka wypracowała także inne spojrzenie na tę kwestię w związku z nawiązaniem do szerszego zjawiska, jakim są czynności operacyjno-rozpoznawcze. Mianowicie wskazuje się również taką cechę jak np. przedprocesowy charakter czynności operacyjno-rozpoznawczych. L. Schaff opracował właśnie taką definicję, dodając do niej także to, że czynności tego typu mają wykonawczą funkcję w stosunku do postępowania przygotowawczego i rozpoznawczego ${ }^{5}$. W innych definicjach wskazuje się na takie elementy jak:

- pozaprocesowość,

- zbieranie informacji,

- działanie w celu ustalenia zamiarów, jak również działalności przestępczej,

${ }^{1}$ R. JaniszowsKi-Downarowicz: Granice dozwolonej prowokacji w polskim prawie karnym. Prok. i Pr. 2009, nr 3, s. 87.

${ }^{2}$ http://sjp.pwn.pl/sjp/prowokacja;2509134.html [dostęp: 11.03.2017].

${ }^{3}$ Ibidem.

${ }^{4}$ A. TARAcha: Czynności operacyjno-rozpoznawcze. Aspekty kryminalistyczne i prawnodowodowe. Lublin 2008.

${ }^{5}$ L. SCHAFF: O niektórych problemach dotyczqcych zakresu postępowania rozpoznawczego. NP. 1957 , nr 12. 
- ujawnianie przestępstw dotąd nieznanych funkcjonariuszom,

- drogę przepływu informacji o przestępstwach i zagrożeniach,

- niejawność działań,

- kompetencje organów znajdują umocowanie w ustawach,

- celowość i świadomość w działaniu funkcjonariuszy,

- służebny charakter tychże działań w stosunku do procesu karnego,

- system działań6.

W literaturze wyróżnia się podział na prowokację czynną i bierną, w oparciu o kryterium interakcji działań. Pierwszy rodzaj charakteryzuje rodzaj uprawnień, które w Polsce posiada Policja. Może ona podejmować działania zmierzające do realizacji zakupu kontrolowanego w każdym z jego rodzajów, w szczególności jeśli chodzi o zbycie przedmiotów, które pochodzą z przestępstwa, a które to zawierają element bezpośredniego, a zatem aktywnego, oddziaływania na nabywców. Zalicza się tu czynności takie jak silna sugestia, oferowanie czy nakłanianie ${ }^{7}$. Drugie z wymienionych odnosi się do innych służb, takich jak np. Agencja Bezpieczeństwa Wewnętrznego, które to przecież nie mają tak rozległych uprawnień jak Policja, ale mogą podejmować czynności operacyjno-rozpoznawcze ${ }^{8}$.

\section{Geneza prowokacji}

Samej genezy omawianego zjawiska doszukiwać się można już w polskim ustawodawstwie karnym z lat 1932 i 1969. Umieszczono je wówczas w postaci odrębnych paragrafów w przepisach dotyczących czynnego żalu w sytuacji podżegania i pomocnictwa. Kodeksy te wyłączały możliwość bezkarności czy też nadzwyczajnego złagodzenia kary lub od odstąpienia od jej wymierzenia w stosunku do osoby prowokatora, jeśli chodzi o sytuacje, w których osoba ta zapobiegła dokonaniu czynu zabronionego lub też starała się mu zapobiec (w przypadku gdy wcześniej nakłoniła do dokonania czynu przestępczego) w celu skierowania przeciwko niemu postępowania karnego?

${ }^{6}$ Zob. T. HanauseK: Kryminalistyka. Zarys wykładu. Kraków 1998; J. Krwawicz, M. LIPKA: O rozpracowaniach operacyjnych. Warszawa 1963; S. PIKULSKI: Urząd Ochrony Państwa. Karnomaterialne i kryminologiczne aspekty bezpieczeństwa państwa. Red. S. SAGAN. Katowice 1992; Z. UnIszEwski: Żargon zawodowy pracowników śledczych i operacyjnych. Problematyka kryminalistyczna. Wrocław 1999.

${ }^{7}$ J. MąKa: Instytucja prowokacji w praktyce dziatania stużb policyjnych. Prok. i Pr. 2010, nr 1-2, s. 154.

${ }^{8}$ Ibidem, s. 155.

${ }^{9}$ Chodzi o art. 30 § k.k. z 1932 r. i o art. $21 \S 3$ k.k. z 1969 r. Przepisy te normowały także kwestie dotyczące wystąpienia czynnego żalu ze strony podżegacza pod warunkiem, że był on skuteczny. Wówczas umożliwiano odstąpienie od kary. Natomiast jeśli 
W polskim prawie karnym instytucja ta jest określona art. 24 Kodeksu karnego ${ }^{10}$. Tym samym, przepisem tym reguluje się odpowiedzialność, gdy chodzi o działanie polegające na nakłanianiu innych osób do popełnienia czynu zabronionego, mającego na celu skierowanie przeciwko tej osobie postępowania karnego. Zgodnie z tym przepisem celem takiego działania nie jest faktyczne dokonanie czynu zabronionego prawem przez osobę, którą się nakłania, ale uzyskanie rezultatu w postaci konsekwencji podjęcia przez tę osobę zachowania będącego przestępstwem i wszczęcie postępowania. Zatem jeśli nie określi się takiego celu, nie można mówić o prowokacji. Jak wskazuje R. Janiszowski-Downarowicz, wskazane przepisy umożliwiały podleganie odpowiedzialności karnej nie tylko osobie sprowokowanej, ale zakładały również odpowiedzialność prowokatora, którego wyłącznym celem była chęć pociągnięcia do odpowiedzialności karnej osoby prowokowanej ${ }^{11}$. Janiszewski-Downarowicz wskazuje także, iż był to swoisty błąd ustawodawcy, bowiem przepisy nie wskazywały rodzaju odpowiedzialności karnej prowokatora i tym samym czyniły go podżegaczem szczególnego rodzaju.

Doktryna zrównuje prowokatora, czy też podżegacza, do osoby agenta policyjnego, którego celem jest wykazanie się skutecznością ujawniania i ścigania przestępstw. W konsekwencji więc najpierw nakłaniali oni przestępców do popełniania czynów zabronionych, aby później im zapobiec. Wyłączenie bezkarności takich osób ma swoje uzasadnienie w interesie społecznym szeroko rozumianym, bowiem u podstaw takiego interesu leży unikanie, a w efekcie eliminowanie zachowań zmierzających do łamania prawa, a nie tworzenie sztucznych okoliczności zmierzających do pociągnięcia kogoś do odpowiedzialności karnej. Motywami owych agentów policyjnych częstokroć było promowanie własnej osoby jako wyróżniającej się wykryciem i zapobieżeniem przestępstwu. Nie można tu także zapomnieć o takich cechach jak zwykła złośliwość czy chęć zemsty ${ }^{12}$.

Kluczowym w tym miejscu może być wyrok Europejskiego Trybunału Praw Człowieka z dnia 9 czerwca 1998 r., orzeczony w sprawie Teixeira de Castro przeciwko Portugalii ${ }^{13}$. Sprawa dotyczyła prowokacji agentów, w której mieli oni nakłonić skarżącego do nabycia trzech porcji heroiny. Wskazano, iż policja zastosowała tę metodę pomimo faktu, że nie miała

czynny żal okazał się bezskuteczny, zakładano możliwość zastosowania nadzwyczajnego złagodzenia kary lub odstąpienia od jej wymierzenia - za: Kodeks karny. Część ogólna. Komentarz. T. I. Red. A. ZolL. Kraków 2004, s. 447.

${ }^{10}$ Dz.U. 1997, nr 88, poz. 553 z późn. zm.

${ }^{11}$ R. Janiszowski-Downarowicz: Granice dozwolonej prowokacji..., s. 88.

${ }^{12}$ Kodeks Karny. Część ogólna. Komentarz. Red. G. Rejman. Warszawa 1999, s. 671.

${ }^{13}$ Wyrok z dnia 9 czerwca 1998 r. w sprawie 44/1997/828/1034, Teixeira de Castro p. Portugalii. 
żadnych podstaw, by podejrzewać de Castro o taką działalność. Policja wskazała tym samym, że de Castro uczestniczy w nielegalnym obrocie narkotykami i jest człowiekiem, który miał ułatwiać zdobycie narkotyków. W sprawie uczestniczyła także V.S., która stwierdziła, że ułatwił on jej dostęp do środków odurzających, wskazując także, że tylko słyszała o de Castro od innej osoby. W przypadku skarżącego wykazano, iż nie był on wcześniej karany oraz że nie znaleziono substancji tego typu w jego mieszkaniu. Trybunał stwierdził w tej sprawie, że funkcjonariusze dopuścili się czynności, która ostatecznie spowodowała nierzetelność postępowania, bowiem dopuścili się podburzenia skarżącego do popełnienia przestępstwa. Trybunał wskazał także naruszenie art. $6 \S 1$ Konwencji o ochronie praw człowieka i podstawowych wolności. Wyrok ten jest wyraźnym przykładem naruszenia granicy wyznaczonej moralnością i etyką zawodową funkcjonariuszy. Pokazuje również, jak różnie można interpretować przepisy o granicy dozwolonej prowokacji.

Wracając do zagadnienia prowokacji, regulowanego art. 24 k.k., wskazać należy, iż błędnie myli się sens znaczenia potocznego przepisu, który odnosi się do działania, które podjęte jest bez zamiaru wszczęcia przeciw osobie prowokowanej postępowania karnego. Wówczas mówi się o zwykłym wyzwaniu kogoś do podjęcia działań przestępczych ${ }^{14}$. Jak wskazuje Janiszowski-Downarowicz: „W takiej sytuacji mamy do czynienia z instytucją prowokacji (a także retorsji) w rozumieniu art. 216 \$ 3 k.k., art. 217 $\S 2$ k.k., art. 222 \$2 k.k. i art. $226 \S 2$ k.k. Jest to działanie inicjowane przez drugą stronę czynu zabronionego, a więc przez pokrzywdzonego, który pomimo wyzywającego zachowania nie staje się jednak podmiotem przestępstwa" 15 . Nie uchyla się tym samym bezprawności czynu, jednak umożliwia się sądom odstąpienie od kary.

Zgodnie z powyższymi rozważaniami nakłanianie innej osoby do popełnienia czynu zabronionego w celu wszczęcia postępowania karnego nie spełnia podmiotowych przesłanek odpowiedzialności za podżeganie. $\mathrm{W}$ tym przypadku celem prowokatora nie jest doprowadzenie osoby trzeciej do popełnienia czynu zabronionego. Głównym celem jest stworzenie solidnych podstaw dających umocowanie do wszczęcia postępowania przeciwko osobie popełniającej czyn zabroniony. W związ-

14 „Prowokacja jest to działanie podjęte w celu skłonienia innej osoby do popełnienia przestępstwa, aby przeciwko tej osobie skierowane zostało postępowanie karne (art. 24 k.k.). Błędnie używa się w języku potocznym tego określenia odnośnie działania podjętego bez takiego zamiaru polegającego na zachowaniu wyzywającym" - Wyrok SA w Krakowie z dnia 1 lipca 2004 r., II AKa 128/04, KZS 2004, nr 7-8, poz. 47.

${ }^{15}$ R. JaniszowsKi-Downarowicz: Granice dozwolonej prowokacji..., s. 89. 
ku z brakiem pierwszego ze wskazanych celów nie można więc mówić o prowokacji ${ }^{16}$.

Jak już zaznaczono wcześniej, prowokator jest zainteresowany jedynie rezultatem podjętych przez niego działań. Osoba ta nie chce, aby sprowokowany dokonał czynu zabronionego jako takiego, więc zapobiega temu poprzez skierowanie na drogę postępowania sądowego. Na kanwie powyższych rozważań uwidacznia się wyraźna różnica między prowokacją a podżeganiem. Mianowicie, jeśli mowa o pierwszym, przestępstwo wykonane może być w każdej fazie rozwoju, natomiast jeśli chodzi o drugie, istotnym celem jest wykonanie przestępstwa bezpośrednio przez inną osobę. W rzeczywistości omawiane przepisy wprowadzają tylko usiłowanie popełnienia przestępstwa - $\mathrm{w}$ przypadku prowokacji $-\mathrm{z}$ uwagi na zatrzymanie tego procederu $\mathrm{w}$ stosownym czasie, umożliwiającym postawienie sprowokowanego $\mathrm{w}$ stan oskarżenia ${ }^{17}$.

\section{Odpowiedzialność prowokatora w świetle art. 24 k.k.}

Jeśli chodzi o odpowiedzialność prowokatora, która usankcjonowana została przepisem art. 24 k.k., wskazuje na jej podstawę jako „odpowiedzialności jak za podżeganie”. Mianowicie chodzi o to, aby prowokator wypełnił znamiona przestępstwa określonego właśnie tym przepisem, a także w przepisie, który wskazuje znamiona przestępstwa, czy czynu zabronionego, który to z kolei jest objęty zamiarem prowokatora. Wskazane wcześniej sformułowanie odsyła do przepisu art. 19 § 1 k.k. ${ }^{18}$.

Warto nadmienić, że odpowiedzialność określoną art. 24 k.k. można wyłączyć przepisami szczególnymi. Chodzi mianowicie o sytuację, w której przepisy lex specialis wskazują na zasady funkcjonowania organów wykrywających i ścigających przestępstwa. Tym sposobem legalizuje się bowiem działania zmierzające do nabycia w sposób niejawny przedmiotów lub przejęcie przedmiotów, które pochodzą z przestępstwa. To może być także wręczenie korzyści majątkowej osobie trzeciej. Wszystko to do-

${ }^{16}$ Wyrok SA w Krakowie z dnia 21 września 2000 r., II AKa 152/00, KZS 2000, nr 10, poz. 30.

${ }^{17}$ Potwierdzeniem jest wyrok ETPC z dnia 5 lutego 2008 r. w sprawie 74420/01, Ramanauskas p. Litwie, w którym Trybunał stwierdził, iż „z prowokacją policyjną (podżeganiem) mamy do czynienia wówczas, gdy funkcjonariusze służb bezpieczeństwa lub osoby działające na ich wniosek nie ograniczają się do wykrywania działalności przestępczej w sposób co do zasady bierny (in an essentially passive manner; d'une manire purement passive), lecz wywierają taki wpływ na osobę poddaną prowokacji w celu uzyskania dowodów i ścigania jej, aby ją nakłonić do popełnienia przestępstwa, którego w innym wypadku by nie popełniła".

${ }^{18}$ R. JANISZOWSKI-Downarowicz: Granice dozwolonej prowokacji..., s. 91. 
tyczy sytuacji, kiedy mowa o czynnościach zmierzających do sprawdzenia wiarygodności i prawdziwości posiadanych przedmiotów czy informacji lub gdy celem jest pozyskanie dowodów umożliwiających wykrycie sprawców. Odnosi się to do czynności podejmowanych przez organy policyjne $\mathrm{w}$ różnych krajach. Mianowicie przy pomocy instrumentów tego typu dochodzi do rozpracowywania groźnych grup zorganizowanych. Wyłącza się tym samym funkcjonariuszy spod wykorzystania przeciwko nim znamion wynikłych $\mathrm{z}$ art. 24 k.k.

\section{Czynności operacyjno-rozpoznawcze w świetle ustawodawstwa polskiego}

W związku z powyższym nawiązać należy w tym miejscu do art. 19 ust. 1 Ustawy z dnia 6 kwietnia 1990 r. o Policji ${ }^{19}$. Mowa tutaj o czynnościach operacyjno-rozpoznawczych, które zmierzają do sprawdzenia pozyskanych wcześniej informacji, ustalenia sprawców i pozyskania dowodów przestępstwa. Mogą one opierać się na czynnościach mających na celu niejawne nabycie, zbycie czy też przejęcie przedmiotów pochodzących z przestępstwa, a także takich, których przewożenia, posiadania czy wytwarzania zabroniono. Czynności o tym charakterze mogą polegać też na propozycji nabycia, zbycia czy przejęcia przedmiotów, które pochodzą z przestępstwa.

Tego samego typu przepisy można znaleźć w ustawach o innych służbach. Są to takie organy jak: Agencja Bezpieczeństwa Wewnętrznego i Agencji Wywiadu ${ }^{20}$, Żandarmeria Wojskowa ${ }^{21}$, Centralne Biuro Antykorupcyjne ${ }^{22}$ oraz Straż Graniczna ${ }^{23}$. Czynności operacyjne, o których mowa, mogą zostać zarządzone przez komendantów służb wskazanych wyżej. Na wszczęcie takich czynności we wszystkich sprawach niezbędna jest zgoda właściwego miejscowo prokuratora okręgowego, wyrażona na piśmie. Z kolei jeśli mowa o CBA i ABW, to pisemną zgodę na podjęcie czynności przez te organy wyrazić musi Prokurator Generalny, który zastrzega również konieczność informowania o przebiegu takich czynności. Co ważne ustawy zawierają klauzę, iż czynności, o których mowa, nie mogą wyczerpać znamion przestępstwa. Ważne jest tutaj, aby czynności,

${ }^{19}$ Dz.U. 1990, nr 30, poz. 179 z późn. zm.

${ }^{20}$ Art. 29 Ustawy o Agencji Bezpieczeństwa Wewnętrznego i Agencji Wywiadu, Dz.U. 2002, nr 74, poz. 676 z późn. zm.

${ }^{21}$ Art. 32 Ustawy o Żandarmerii Wojskowej, Dz.U. nr 123, poz. 1353 z późn. zm.

${ }^{22}$ Art. 19 Ustawy o Centralnym Biurze Antykorupcyjnym, Dz.U. 2006, nr 104, poz. 708 z późn. zm.

${ }^{23}$ Art. 9f Ustawy o Straży Granicznej, Dz.U. 1990, nr 78, poz. 48 z późn. zm. 
które podejmują agenci czy funkcjonariusze, nie przybrały negatywnego, bezprawnego wydźwięku, sprowadzającego się do nakłaniania do popełnienia przestępstwa osób przypadkowych.

Nadmienić w tym miejscu należy, iż wskazane wcześniej przepisy, pochodzące z ustaw, umożliwiają zastosowanie dozwolonej prowokacji wyłącznie w przypadku, gdy uzyskają wiarygodne umocowanie w postaci informacji o popełnionym przestępstwie i opierać się będą na ocenie tej wiarygodności przez pryzmat kategorii prawdopodobieństwa, pochodzących z Kodeksu karnego.

Granica dopuszczalnej prowokacji legalnej wyrażona została przez Janiszowskiego-Downarowicza w słowach: „w wypadku działania na podstawie regulacji dopuszczających prowokację niezbędnym warunkiem ich legalności jest brak działania funkcjonariusza stosującego tę metodę $\mathrm{w}$ celu skierowania postępowania karnego przeciwko osobie prowokowanej. Funkcjonariusz nie może więc nakłaniać do popełnienia przestępstwa bądź organizować albo kierować działaniami przestępczymi" ${ }^{24}$.

Powyższe rozważania sprowadzają się do stwierdzenia, iż omawiane zjawisko jest wyższym poziomem działalności, sferą, która powinna być następstwem stosowania metody podsłuchu, współpracy z różnorakimi źródłami informacji, a także obserwacji. Do szczególnych rodzajów prowokacji policyjnej należy także zaliczyć wyliczone w ustawodawstwie wręczenie kontrolowane, nadzorowaną niejawnie przesyłkę czy też zakup kontrolowany.

Zgodnie z Rozporządzeniem Ministra Spraw Wewnętrznych i Administracji z dnia 27 maja 2002 r. w sprawie szczególnych zasad i trybu wydawania, posługiwania się, przechowywania i ewidencji dokumentów, które uniemożliwiają ustalenie danych identyfikujących policjanta lub osobę udzielającą pomocy Policji oraz środków, którymi posługują się przy wykonywaniu zadań służbowych ${ }^{25}$ wszystkie działania operacyjno-rozpoznawcze, w tym prowokacja jako taka, są zabezpieczone klauzulą zapewnienia wszystkim przedsięwzięciom policyjnym środków koniecznych do zagwarantowania całkowitego i kompleksowego bezpieczeństwa osobistego zarówno funkcjonariuszy, jak również osób udzielających pomocy. Jest to związane $\mathrm{z}$ faktem, iż umożliwia się udział $\mathrm{w}$ takich działaniach także osobom, które nie są funkcjonariuszami. Możliwość taką zakłada wspomniany wcześniej art. 19a ustawy o Policji. Dane identyfikacyjne osoby pomagające policjantom/agentom w rozpracowywaniu grup przestępczych opatrzone są klauzulą ścisłej tajemnicy. Ujawnienia takich danych może żądać wyłącznie prokurator, również w związku z podejrze-

\footnotetext{
${ }^{24}$ R. Janiszowski-Downarowicz: Granice dozwolonej prowokacji..., s. 93.

${ }^{25}$ Dz.U. nr 74, poz. 684.
} 
niem dotyczącym popełnienia przez tę osobę przestępstwa, które jest ścigane z oskarżenia publicznego. Zakres obowiązków należących do takich osób ogranicza się do przyjęcia korzyści majątkowych, udziału w zakupie kontrolowanym czy też w kontrolowanym przyjęciu korzyści ${ }^{26}$.

\section{Podsumowanie}

Na koniec należy sobie zadać pytanie, jak daleko można przesunąć stosowanie przepisów o odpowiedzialności, zważywszy na katalog instytucji mogących stosować takie techniki. Tutaj warto wspomnieć o ustawodawstwie amerykańskim, które umożliwia agentowi tak podżeganie, jak i czynne uczestniczenie $\mathrm{w}$ procederze. $\mathrm{W}$ tym przypadku bada się i ocenia predyspozycje i skłonności osoby podżeganej i jeśli ustali się brak oznak do popełnienia przestępstwa przed poznaniem agenta, wówczas uniewinnia się taką osobę. Jeśli natomiast sytuacja jest odwrotna i sprawca miał wcześniej do czynienia z przestępstwami podobnego typu, wówczas nie ma możliwości uniewinnienia go. Musi tu natomiast istnieć realne ryzyko, iż osoba dopuści się przestępstwa w normalnych warunkach. Można więc mówić o swoistej weryfikacji obywateli przez Policję i nie jest konieczne wypełnienie przesłanki posiadania wcześniej wiarygodnych informacji o możliwości dokonania czynu zabronionego ${ }^{27}$.

Wnioskując powyższe rozważania, przytoczyć można konkluzje cytowanego wcześniej autora. Mianowicie, że poszerzenie funkcjonujących $\mathrm{w}$ obecnych warunkach granic uprawnień prowokatora $\mathrm{z}$ tytułu moralności jest niezasadne. Zasadne natomiast wydaje być w tym miejscu powiedzenie, że im więcej ma się uprawnień i możliwości, tym bardziej prawdopodobne staje się zepsucie. Możliwość taka otwarłaby drzwi dla wykorzystywania omawianej instytucji do walki politycznej, która w dzisiejszych czasach i tak angażuje różne źródła pozyskiwania informacji niewygodnych dla opozycji. Wyobraźmy sobie bowiem sytuację, gdy obóz opozycji, czy to w Polsce, czy w jakimkolwiek innym kraju, wykorzystuje prowokację w celu uzyskania informacji na temat osób rządzących. Nietrudno się domyślić, że informacje takie byłyby chętnie wykorzystywane, co prowadziłoby do kolejnych patologii i wynaturzeń. Powyższe sprowadza się także do utraty zaufania do wymiaru sprawiedliwości oraz ustawodawstwa, co z kolei prowadzi do wszelkich wynaturzeń związanych z demokracją i prawami człowieka, a także ochroną tych syste-

${ }^{26}$ T. CzyloK, P. PodsieduIK: Zakup kontrolowany, przyjęcie lub wręczenie korzyści majątkowej. Katowice 2012, s. 16.

${ }^{27}$ W. GonTARSKI: Jednoaktówka CBA. Gazeta Sądowa 2007, nr 7-8, s. 3. 
mów. Zadajmy sobie więc pytanie, czy połączenie organu Prokuratora Generalnego i Ministra Sprawiedliwości w zakresie sprawowania kontroli i zezwalania na wykonywanie czynności operacyjnych nie jest zręcznym narzędziem w rękach osoby sprawującej ten urząd. Odnośnie do tej kwestii warto przytoczyć Ustawę z dnia 28 stycznia 2016 r. - Prawo o prokuraturze $^{28}$. Ustawa ta poza koniecznością informowania o liczbie prowadzonych czynności operacyjno-rozpoznawczych i kontrolą prokuratora nad tymi czynnościami zakłada także możliwość poznania materiałów dotyczących tychże czynności wraz z możliwością zniesienia klauzuli tajności po zasięgnięciu informacji od organu prowadzącego czynności i poinformowaniu o tym Prezesa Rady Ministrów. Tym samym nie zagwarantowano niezależności Prokuratora Generalnego / Ministra Sprawiedliwości. Co istotne, kompetencje te poszerza się o możliwość przekazania otrzymanych tak informacji także innym osobom, co oznacza, że są to osoby, które nie muszą pełnić funkcji organów władzy publicznej, jeśli tylko informacje takie mogą okazać się ważne czy istotne dla bezpieczeństwa państwa. Założono tym samym kontrolę parlamentarną nad tą kwestią ${ }^{29}$.

Biorąc pod uwagę powyższe, dostrzec można instrumentalizację prawa, podlegającą ocenie przez władzę zwierzchnią. Siląc się w tym miejscu na ocenę skuteczności, stwierdzić należy, iż dotychczasowe próby zmierzające do polepszania systemu działań operacyjno-rozpoznawczych w efekcie doprowadzają do poszerzania uprawnień funkcjonariuszy w tym zakresie. Wiąże się z tym wspomniany wcześniej proces zepsucia, czy może łagodniej - pogarszania się jakości pracy uprawnionych służb. Widoczne jest tutaj zastosowanie przytoczonego wcześniej powiedzenia. Jaki będzie efekt końcowy tego procesu? Ciężko stwierdzić, nie jest bowiem widoczne nagminne nadużywanie uprawnień przez funkcjonariuszy $\mathrm{w}$ omawianym zakresie, ale nie mogę na tym etapie wyraźnie i z przekonaniem stwierdzić, czy konsekwencje w takiej postaci nie nastąpią za trzy, pięć czy dziesięć lat.

Kolejną kwestią pozostaje pytanie, czy nie powinno się zatem rozgraniczyć zakresów kompetencji tych organów w celu usprawnienia systemu, o którym mowa wyżej? Jeśli chodzi o moje osobiste przekonanie należy rozgraniczyć funkcję Ministra Sprawiedliwości od Prokuratora Generalnego, nie tylko z uwagi na problem kontroli czynności operacyjno-rozpoznawczych, ale także z innych względów. Konkretnie chodzi tutaj o zjawisko wiarygodności osoby w opinii publicznej suwerena. W moim przekonaniu naruszenie tej zasady przez Ministra Sprawiedliwości godzi

${ }^{28}$ Dz.U. 2016, poz. 177.

${ }^{29}$ B. GrabowsKa-Moroz, A. Pietryka: Stużby specjalne, policyjne i skarbowe a prawa człowieka - standardy konstytucyjne i międzynarodowe oraz kierunki niezbędnych zmian legislacyjnych. HFPCzł, Warszawa 2016, s. 16. Źródło: http://www.hfhr.pl/wp-content/ uploads/2017/01/SluzbyaPrawaCzlowiekaHFPC.pdf [dostęp: 11.03.2017]. 
w autorytet Prokuratora Generalnego, którego sylwetka winna być nieskazitelna. Jak więc osoba, której wizerunek z jakiś względów został obarczony zachwianiem zaufania, może pełnić jednocześnie funkcję niezawisłego Prokuratora? W mojej ocenie osoba taka nie jest wiarygodna w pełnieniu swojej doniosłej prawnie funkcji, z uwagi na niemożność rozdwojenia się jednej osoby. Bo albo się jest wiarygodnym w całej okazałości, albo się nie jest godnym zaufania wcale. Odnosi się to także do przepisów umożliwiających przekazanie pozyskanych w toku czynności operacyjno-rozpoznawczych informacji osobom trzecim, wyłączających klauzulę tajności w określonych przypadkach. W moim przekonaniu działanie takie jest nacechowane negatywnie. Opinię tę potwierdza także wspomniany wyżej raport Helsińskiej Fundacji Praw Człowieka.

I najważniejsze, czy nie usprawniłoby to działania służb w tym zakresie i skuteczności ścigania przestępczości? Zmiany ustawodawstwa odnoszące się do funkcjonowania służb i poszerzania ich kompetencji w dużym stopniu moga pozytywnie wpływać na skuteczność wykrywania i ścigania, a w konsekwencji eliminowania przestępstw, bowiem umożliwia działanie w szerszych kręgach w odniesieniu do ewolucji przestępczości jako takiej.

Stawiając powyższe pytania, należy także wziąć pod uwagę, iż omawiana instytucja jest ochroną dla obywateli przed rosnącą falą przestępczości, ale także przed nieuprawnioną ingerencją w prawa i wolności, zagwarantowane Konstytucją RP, a nie narzędziem zmierzającym do poszerzania zakresu kompetencji organów czy osoby rządzącej.

\section{Bibliografia}

\section{Literatura}

Czylok T., Podsiedlik P.: Zakup kontrolowany, przyjęcie lub wręczenie korzyści majątkowej. Katowice 2012.

GonTARSKI W.: Jednoaktówka CBA. „Gazeta Sądowa” 2007, nr 7-8.

HANAUSEK T.: Kryminalistyka. Zarys wykładu. Kraków 1998.

JANISZOWSKI-DownARowicz R.: Granice dozwolonej prowokacji w polskim prawie karnym. Prok. i Pr. 2009, nr 3.

KrWAWICZ J., LiPKA M.: O rozpracowaniach operacyjnych. Warszawa 1963.

MąкA J.: Instytucja prowokacji $w$ praktyce dziatania stużb policyjnych. Prok. i Pr. 2010, nr 1-2.

PIKULSKI S.: Urzad Ochrony Państwa. Karnomaterialne i kryminologiczne aspekty bezpieczeństwa państwa. Red. S. SAGAN. Katowice 1992.

SCHAFF L.: O niektórych problemach dotyczacych zakresu postępowania rozpoznawczego. NP. 1957, nr 12.

Taracha A.: Czynności operacyjno-rozpoznawcze. Aspekty kryminalistyczne i prawnodowodowe. Lublin 2008. 
UNISZEWSKI Z.: Żargon zawodowy pracowników śledczych i operacyjnych. Problematyka kryminalistyczna. Wrocław 1999.

\section{Orzecznictwo}

Wyrok SA w Krakowie z dnia 21 września 2000 r., II AKa 152/00, KZS 2000, nr 10 , poz. 30 .

Wyrok SA w Krakowie z dnia 1 lipca 2004 r., II AKa 128/04, KZS 2004, nr 7-8, poz. 47.

Wyrok ETPC z dnia 9 czerwca 1998 r. w sprawie 44/1997/828/1034 Teixeira de Castro p. Portugalii.

\section{Źródła internetowe}

Grabowska-Moroz B., Pietryka A.: Stużby specjalne, policyjne i skarbowe a prawa człowieka - standardy konstytucyjne $i$ międzynarodowe oraz kierunki niezbędnych zmian legislacyjnych. HFPCzł, Warszawa 2016. Źródło: http://www.hfhr. pl/wp-content/uploads/2017/01/SluzbyaPrawaCzlowiekaHFPC.pdf [dostęp: 11.03.2017].

http://sjp.pwn.pl/sjp/prowokacja;2509134.html [dostęp: 11.03.2017]. 